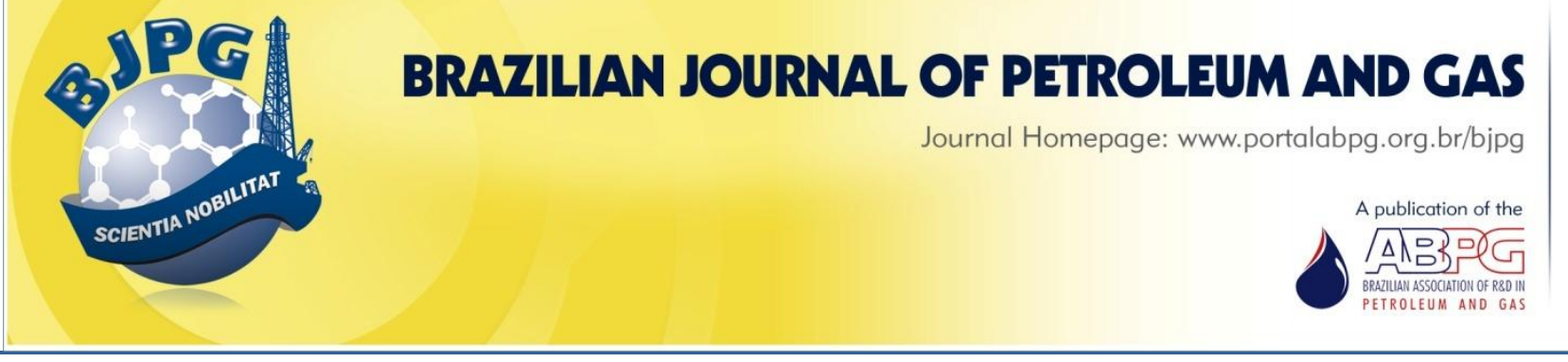

\title{
USING MICROEMULSION-MODIFIED DIATOMITE FOR REMOVING SULFUR FROM COMMERCIAL DIESEL
}

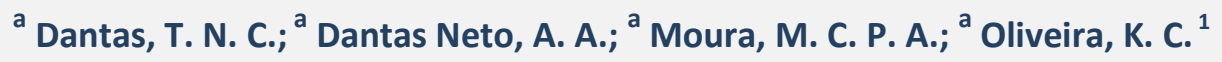 \\ ${ }^{a}$ Department of Chemical Engineering, Federal University of Rio Grande do Norte (UFRN), Rio Grande do Norte - RN, Brazil
}

Received: 22.11.2017 / Revised: 08.12.2017 / Accepted: 08.12.2017 / Published on line: 21.12.2017

\begin{abstract}
Diatomite or diatomaceous earth is a sedimentary rock composed mainly of diatom siliceous skeletons with high porosity that is often used in adsorption processes. This work investigates the enhancement of diatomite properties using microemulsion systems in the removal of sulfur from commercial diesel. Nonionic surfactants containing microemulsions were used to modify its surface. The adsorbents were characterized by scanning electron microscopy (SEM), X-ray diffraction (XRD), X-ray fluorescence (XRF), thermogravimetry (TG), and $\mathrm{N}_{2}$ adsorption-desorption. A $2^{3}$ full factorial design was performed to assess the influence of salt concentration on adsorption capacities in the microemulsion aqueous phase (from 20 to $1500 \mathrm{mg} / \mathrm{kg}$ ). The experiments were carried out at batch temperature (25 to $60{ }^{\circ} \mathrm{C}$ ) and using a commercial diesel fuel with sulfur concentration from 300 to $1100 \mathrm{mg} / \mathrm{kg}$. Sulfur adsorption capacity increased from $0.436 \mathrm{mg} / \mathrm{g}$ to $1.23 \mathrm{mg} / \mathrm{g}$ with the optimization of the microemulsion system and with the salt addition. The microemulsion-modified diatomite was able to remove up to $26.53 \%$ sulfur from commercial diesel.
\end{abstract}

\section{KEYWORDS}

commercial diesel; diatomite; microemulsion; desulfurization; adsorption

\footnotetext{
${ }^{1}$ To whom all correspondence should be addressed.

Address: Department of Chemical Engineering, Federal University of Rio Grande do Norte (UFRN), Campus Universitário, Natal, RN, Brazil.

ZIP Code: 59070-970 | Telephone: +55 84 3215-3156 |e-mail: kathy carrilho@hotmail.com

doi:10.5419/bjpg2017-0020
} 


\section{INTRODUCTION}

With environmental requirements becoming increasingly stricter, the market demand for cleaner fuels is growing (Fallah \& Azizian, 2012). Sulfur is one of the main contaminants of fossil fuels and, when present in high amounts, it affects both the environment and human health (Hussain \& Tatarchuk, 2013). To meet climate change commitments, there is a need to develop new methods that are more efficient and economically feasible for promoting sulfur removal. From this standpoint, the development of advanced desulfurization technologies is essential to produce near zero diesel fuels (Bu et al., 2011).

Diatomite or diatomaceous earth represents an economically viable alternative in adsorption processes because the material is abundant and has characteristics that make the process economically viable. It has a high mesoporosity and/or macroporosity, low thermal conductivity, good acid resistance and hydrophobic character, among many others unique physical and chemical characteristics (Yu et al., 2015). As a result, diatomaceous earth is used widely in the removal of pollutants, such as heavy metals and micro pollutants, from water (Al-Degs et al., 2001; Chu et al., 2012; Dantas et al., 2001b; Khraisheh et al., 2004; Osmanlioglu, 2007). It is a promising material for use in filtration operations and to eliminate radioactivity from liquid waste (Osmanlioglu, 2007; Yusan et al., 2012). Diatomite, in its raw form, has an ordinary capacity for adsorbing organic molecules (Aivalioti et al., 2010). The reduced adsorption affinity for organics is due to impurities and the presence of a silanol group in its structure (Jiang et al., 2016; Yu et al., 2015). Thus, to improve diatomite adsorption capacity, researchers seek to develop methods to modify the diatomite surface. Surfactant agents have been used for this purpose (Al-Ghouti \& Al-Degs, 2011; Dantas et al., 2001b; Sprynskyy et al., 2010).

Microemulsions are thermodynamically stable systems containing a mixture of two immiscible liquids stabilized by surfactants with or without the aid of a cosurfactant, such as a short-chain alcohol (Dantas et al., 2001b). Its application in the modification of adsorbents surface, including diatomite surface (Al-Ghouti \& Al-Degs, 2011; Dantas et al., 2001a; Khraisheh \& Al-Ghouti, 2005; Li et al., 2009), has been demonstrated as an efficient process to improve the adsorption of organic and inorganic pollutants (Al-Ghouti et al., 2013; Dantas et al., 2001b). Literature reports that microemulsion clusters can be adsorbed in the porous structure of diatomite, enhancing its adsorption capacity for specific molecules (AlGhouti \& Al-Degs, 2011).

To remove sulfur from fossil fuels, many researches work on developing effective, applicable, and low-cost technologies. Studies using the adsorption process (Al-Ghouti et al., 2010; Muzic et al., 2010; Nejad et al., 2013; Song et al., 2013; Subhan et al., 2012; Teymouri et al., 2013; Wang et al., 2011), oxidative/extractive desulfurization (Chen et al., 2016ab; Julião et al., 2015; Nawaf et al., 2015), and biodesulfurization (Bordoloi et al., 2014; Guchhait et al., 2005; Paixão et al., 2016) have presented effective results.

Muzic et al. (2010) removed sulfur from diesel in batch adsorption experiments using commercial activated carbon (Norit SXRO PLUS) and 13X zeolite. The experiments were carried out using a $2^{3}$ factorial design to evaluate the influence of contact time, adsorbent mass, and temperature. They observed that adsorbent mass and contact time presented the greatest effects, with the best results being achieved using Norit SXRO PLUS activated carbon $(0.1742 \mathrm{mg} / \mathrm{g})$.

Wang et al. (2011) studied the effect of the addition of five surfactant solutions (two anionic, one cationic, and two non-ionic) during the synthesis of pillared clays (Ti-PILCs) from $\mathrm{Na}$ montmorillonite. Zinc nitrate solution was used to obtain zinc-supported adsorbents (Zn/Ti-PILCs), which were used as desulfurization adsorbents. The adsorption was evaluated in finite batch using a synthetic diesel fuel at a concentration of 10 $\mathrm{mmol} / \mathrm{L}$. Clay modified with CTAB (Cetyl trimethyl ammonium bromide) presented the highest percentage of sulfur removal (94.4\%). By optimizing the surfactant concentration, it was possible to obtain a $96.3 \%$ removal of DBT (dibenzotiophene).

In this context, this study reports the use of novel microemulsion-modified diatomites as adsorbents for desulfurization of commercial diesel fuel. Sulfur adsorption capacity was evaluated considering the effects of temperature, salt concentration in the aqueous phase of the 
microemulsion, and the concentration of sulfur in diesel fuel.

\section{MATERIALS AND METHODS}

\subsection{Materials}

The diatomite (Maraxanguape, RN - Brazil) was acquired in its raw form. It was calcined at $850{ }^{\circ} \mathrm{C}$ and grinded in a hammer mill. Nonylphenol ethoxylate with 9.5 mols of ethylene oxide (RNX95), purchased from Oxiteno (Brazil), was used as a non-ionic surfactant. $\mathrm{CaCl}_{2}, \mathrm{BaCl}_{2}$, butan-1-ol, and $n$-hexane were purchased from Vetec, Brazil. Commercial diesel fuels were obtained from two Petrobras refineries: one from Clara Camarão Refinery (Guamaré, RN - Brazil), and the second one from LUBNOR (Fortaleza, CE - Brazil). Table 1 shows its physical properties. These diesel fuels were employed in their original concentrations and mixed with each other to obtain various sulfur concentrations. All reagents were used with no further purification.

\subsection{Methods}

\subsubsection{Microemulsion systems}

The microemulsion area inside the pseudoternary phase diagram was obtained using the titrating methodology (Dantas et al., 2014). In $15-\mathrm{mL}$ borosilicate glass test tubes various proportions of oil phase (n-hexane) and cosurfactant/surfactant phase (butan-1-ol/RNX95 = 1.0) were weighed. After, these mixtures were titrated with the aqueous phase (distilled water) until passing from a clear (microemulsion) to a cloudy system (two-phase system). Three different microemulsion structures inside the microemulsion area (oil-in-water, water-in-oil, and bicontinuous) were used for adsorbent modification. Microemulsion systems were characterized considering: surface tension at $25^{\circ} \mathrm{C}$ (Sensadyne, QC-6000 analyzer), apparent viscosity at $25^{\circ} \mathrm{C}$ and $2000 \mathrm{~s}^{-1}$ shear rate (Brookfield, R/S Rheometer), and droplet diameter/polydispersity at $25^{\circ} \mathrm{C}$ (Instrutécnica, ZetaPlus potencial zeta analyzer).

\subsubsection{Modification of adsorbent surface by using microemulsions}

The diatomite was mixed with RNX95 microemulsions, with various amounts of aqueous phases, using a mechanical stirrer (Tecnal, TE-139) until complete homogenization. A 3:1 ratio between the microemulsion $(\mathrm{mL})$ and diatomite $(\mathrm{g})$ was set based on the volume required to soak the adsorbent completely. $\mathrm{BaCl}_{2}$ and $\mathrm{CaCl}_{2}$ solutions ( 20 to $1500 \mathrm{mg} / \mathrm{kg}$ ) were used to investigate the effect of salt concentration on the removal of sulfur. The microemulsion-wet diatomites were dried on a Biomatic stove at $60^{\circ} \mathrm{C}$, for 24 hours.

\subsubsection{Adsorbent characterization}

The X-ray fluorescence (XRF) was performed on a Shimadzu-1800 XRF spectrometer. The X-ray diffraction (XRD) patterns were obtained on a Shimadzu XRD-7000 Diffractometer equipped with $\mathrm{Cu} \mathrm{K} \alpha$ radiation at $40 \mathrm{kV}$ and $30 \mathrm{~mA}$ in the range of 5 to $80^{\circ}$, at $2^{\circ} / \mathrm{min}$. SEM images were recorded using a scanning electron microscope (Hitachi, TM 3000). Nitrogen adsorption-desorption measurements were performed on a Micromeritics ASAP 2020 adsorption analyzer at $-195.20^{\circ} \mathrm{C}$ using adsorbent samples degassed at $180^{\circ} \mathrm{C}$ for 11 hours prior to the experiments. Thermogravimetric curves were obtained on a TA Instruments

Table 1. Characteristics of the commercial diesel fuels used.

\begin{tabular}{lcc}
\hline \multicolumn{1}{c}{ Property } & \multicolumn{2}{c}{ Value } \\
\cline { 2 - 3 } & $\begin{array}{c}\text { Clara Camarão } \\
\text { Refinery }\end{array}$ & LUBNOR \\
\hline Cetane number & 52.5 & - \\
Kinematic viscosity at $40^{\circ} \mathrm{C}\left(\mathrm{mm}^{2} \mathrm{~s}^{-1}\right)$ & 3.470 & 2.789 \\
Specific mass at $20^{\circ} \mathrm{C}\left(\mathrm{kg} \mathrm{m}^{-3}\right)$ & 834.4 & 827.9 \\
Flash point $\left({ }^{\circ} \mathrm{C}\right)$ & 38 & 69 \\
Total sulfur content $\left(\mathrm{mg} \mathrm{kg}^{-1}\right)$ & 1233.0 & 7.2 \\
\hline
\end{tabular}


Table 2. Real and coded values for the factors used in the $2^{3}$ factorial design.

\begin{tabular}{lccc}
\hline \multicolumn{1}{c}{ Operating variables } & $\mathbf{- 1}$ & $\mathbf{0}$ & $\mathbf{1}$ \\
\hline $\mathrm{X}_{1}$, temperature $\left({ }^{\circ} \mathrm{C}\right)$ & 25.0 & 42.5 & 60.0 \\
$\mathrm{X}_{2}$, salt concentration $(\mathrm{mg} / \mathrm{kg})$ & 20.0 & 760.0 & 1500.0 \\
$\mathrm{X}_{3}$, sulfur concentration $(\mathrm{mg} / \mathrm{kg})$ & 300.0 & 700.0 & 1100.0
\end{tabular}

DSC/TGA Simultaneous Thermal Analyzer using an alumina crucible as sample container, at a synthetic air atmosphere, working under a $50 \mathrm{~mL} / \mathrm{min}$ of purge gas flow rate, and a temperature ramp from $25^{\circ} \mathrm{C}$ to $1200^{\circ} \mathrm{C}$ at a $10^{\circ} \mathrm{C} / \mathrm{min}$ heating rate.

\subsubsection{Sulfur analysis}

The total sulfur in diesel fuel samples were determined before and after adsorption experiments using a sulfur analyzer (Antek Instruments, Model 9000 NS), as per the ASTM D2622 method.

\subsubsection{Batch adsorption experiments}

The adsorption experiments were carried out in 125-mL Erlenmeyer flasks using a thermostatic Dubnoff-type batch (Tecnal, 053 model) with constant stirring $(1200 \mathrm{rpm})$. The ratio between adsorbent $(\mathrm{g})$ and diesel $(\mathrm{mL})$ was fixed at 1:5. The effects of salt concentration in the microemulsion aqueous phase (20 to $1500 \mathrm{mg} / \mathrm{kg}$ ), batch temperature ( 25 to $60{ }^{\circ} \mathrm{C}$ ), and diesel fuel sulfur concentration $(300$ to $1100 \mathrm{mg} / \mathrm{kg}$ ) in the adsorption process were evaluated. Based on Dantas et al. (2014) the contact time was set for 18 hours and, after that, a simple filtration was performed using a qualitative filter paper (Qualy $\varnothing$ $9 \mathrm{~cm}$ ) and a $50-\mathrm{mL}$ glass funnel. The sulfur content was determined in the liquid phase. The adsorption capacity (q) and the percentage of sulfur removal were calculated using Eqs. (1) and (2), respectively.

$\mathrm{q}=\frac{\mathrm{V}\left(\mathrm{C}_{0}-\mathrm{C}_{\mathrm{f}}\right)}{\mathrm{m}}$

Sulfur removal $(\%)=\frac{\left(\mathrm{C}_{0}-\mathrm{C}_{\mathrm{f}}\right)}{\mathrm{C}_{\mathrm{f}}} \times 100$

Where $C_{0}$ and $C_{f}$ are the concentrations of sulfur in diesel fuel before and after adsorption $\left(\mathrm{mg}^{\mathrm{mL}} \mathrm{mL}^{-1}\right), \mathrm{V}$ is the volume of diesel fuel $(\mathrm{mL})$, and $\mathrm{m}$ is the adsorbent mass (g).

\subsubsection{Statistical study}

Statistical analysis was performed using a $2^{3}$ full factorial design. According to this experimental design, eight experiments, with a central point made in triplicate, were carried out. The three factors used were: batch temperature, salt concentration in the aqueous phase of the microemulsion, and concentration of sulfur in diesel. Factor levels with their real and coded values are shown in Table 2 . The experiments were performed in random order and in duplicate. As a result, the average between them was used, except for the central point. Statistical evaluation was performed by using the STATISTICA 7.0 software.

\section{RESULTS AND DISCUSSIONS}

\subsection{Pseudoternary phase diagram}

Figure 1 shows the pseudoternary phase diagram with the microemulsion area. Inside this area, for adsorbent modification, three compositions were selected based on the micellar structure present in each system $(\mu 1 R, \mu 2 R$, and $\mu 3 R$ ) (Table 3).

\subsection{Microemulsion systems characterization}

The physical characterization of the microemulsion systems was carried out by the analysis of: surface tension, apparent viscosity, droplet diameter, and polydispersity. The results are shown in Table 4.

As one can observe, when comparing systems $\mu 1 R(O / W)$ with $\mu 3 R(W / O)$, the decrease in apparent viscosity is explained by the presence of the highest percentage of $n$-hexane $(0.30 \mathrm{cP}$, at $25^{\circ} \mathrm{C}$ ) and the lowest percentage of surfactant. 


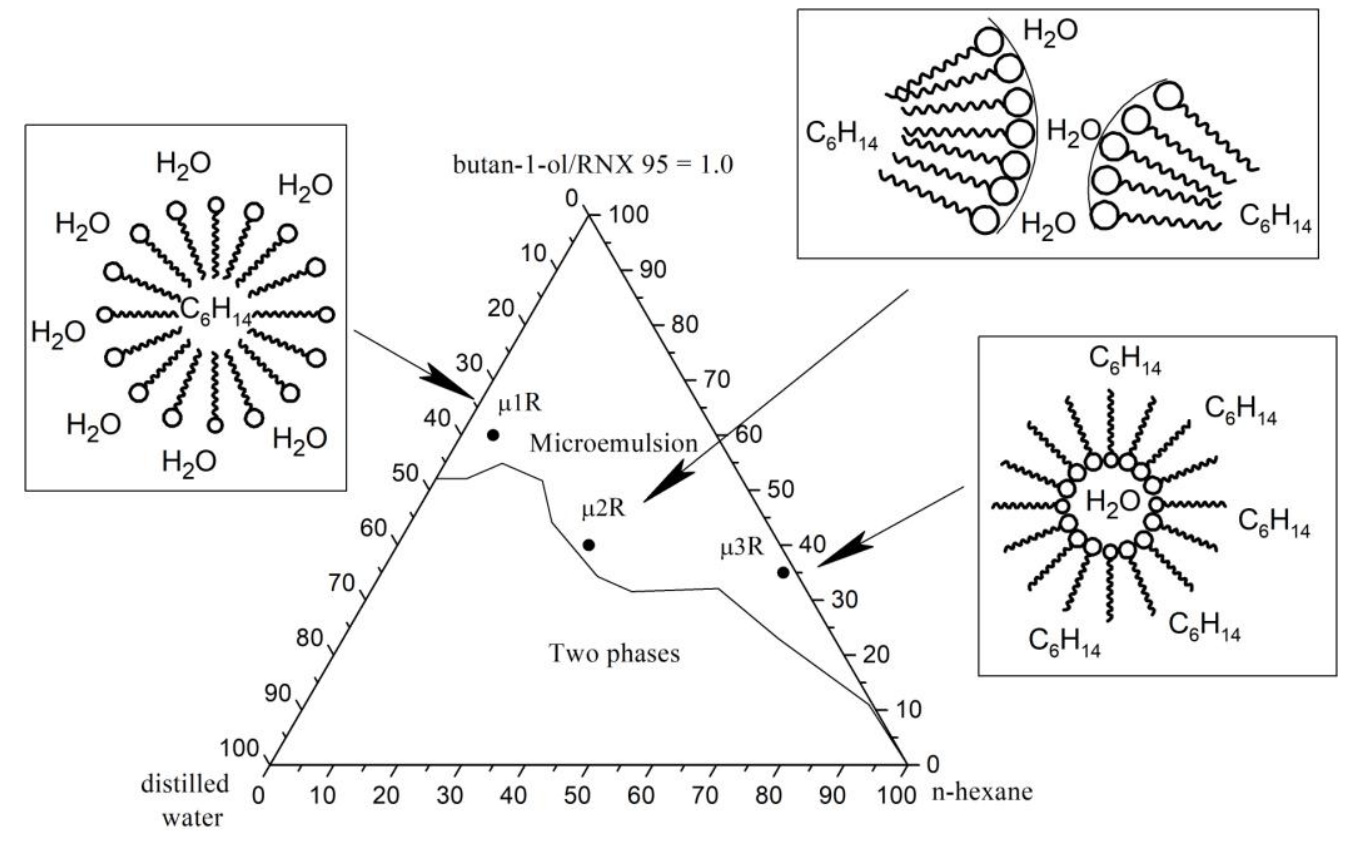

Figure 1. Pseudoternary phase diagram with the microemulsion area and micellar structures (Dantas et al. 2014).

Considering surface tension measurements, the continuous phase influenced the results, considering that the $\mu 3 R$ has less surfactant than $\mu 1 R$. Moreover, the surface tension of $\mu 3 R$ systems was also lower. System $\mu 1 \mathrm{R}(\mathrm{O} / \mathrm{W})$, with water as continuous phase $\left(72.8 \mathrm{mN} / \mathrm{m}\right.$, at $\left.25^{\circ} \mathrm{C}\right)$, had a higher surface tension than system $\mu 3 R(\mathrm{~W} / \mathrm{O})$, which had $\mathrm{n}$-hexane as continuous phase (17.9 $\mathrm{mN} / \mathrm{m}$, at $25^{\circ} \mathrm{C}$ ). Figure 2 shows the diameter distribution for these systems.
Regarding the diameter distribution, it is possible to observe the polydispersity index of the systems in Figure 2, which is represented by the width of the curves. As one can observe, $\mu 1 R$ and $\mu 3 R$ have similar polydispersity indexes with the presence of spherical micelles. For $\mu 2 R$, the polydispersity index was lower due to the presence of lamellar structures formed by the existence of water and oil in equal proportions (Figure 3).

Table 3. Composition of the selected microemulsion systems.

\begin{tabular}{ccccc}
\hline \multirow{2}{*}{ System } & $\begin{array}{c}\text { Microemulsion } \\
\text { structure }\end{array}$ & butan-1-ol/RNX 95 (\%) & $\begin{array}{c}\text { distilled water } \\
\text { (\%) }\end{array}$ & $\begin{array}{c}\text { n-hexane } \\
\text { (\%) }\end{array}$ \\
\hline$\mu 1 R$ & oil-in-water (O/W) & 60 & 35 & 5 \\
$\mu 2 R$ & bicontinuous & 40 & 30 & 30 \\
$\mu 3 R$ & water-in-oil (W/O) & 35 & 2 & 63 \\
\hline
\end{tabular}

Table 4. Physical characterization of microemulsion systems $\left(25^{\circ} \mathrm{C}\right)$.

\begin{tabular}{ccccc}
\hline $\begin{array}{c}\text { Microemulsion } \\
\text { structure }\end{array}$ & $\begin{array}{c}\text { Apparent } \\
\text { viscosity (cP) }\end{array}$ & $\begin{array}{c}\text { Surface } \\
\text { tension } \\
(\mathbf{m N} / \mathbf{m})\end{array}$ & $\begin{array}{c}\text { Droplet } \\
\text { diameter } \\
(\mathbf{n m})\end{array}$ \\
\hline$\mu 1 \mathrm{R}$ & $\mathrm{O} / \mathrm{W}$ & 9.5 & 26.2 & 180.2 \\
$\mu 2 \mathrm{R}$ & Bicontinuous & 6.0 & 20.4 & 174.0 \\
$\mu 3 \mathrm{R}$ & $\mathrm{W} / \mathrm{O}$ & 3.0 & 17.4 & 194.1 \\
\hline
\end{tabular}




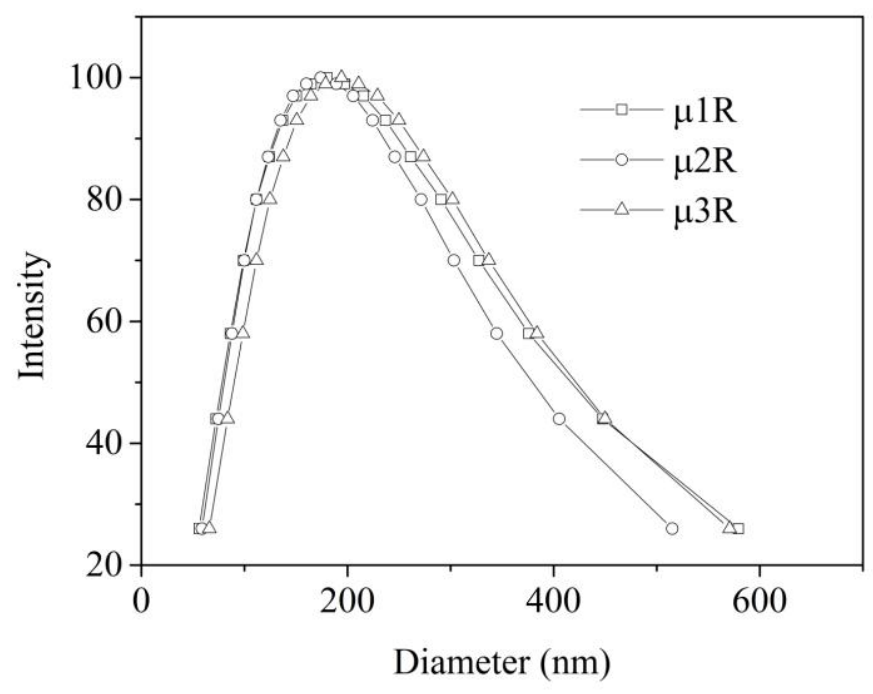

Figure 2. Diameter distribution for $\mu 1 R, \mu 2 R$, and $\mu 3 R$.

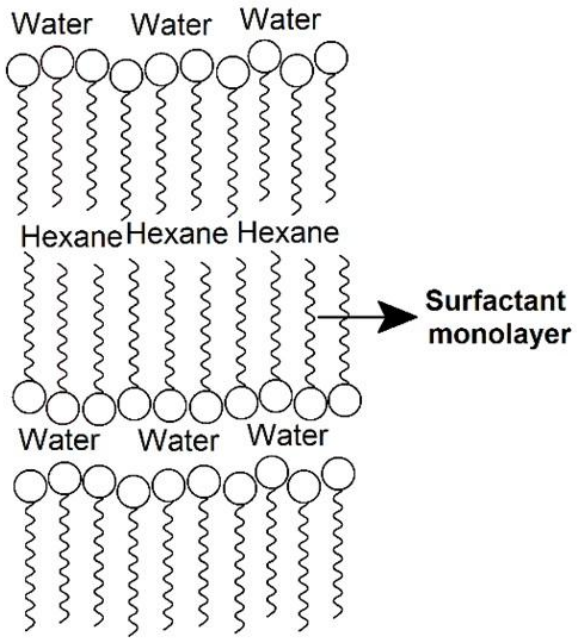

Figure 3. Schematic illustration of a bicontinuous microemulsion.

Observing the data of droplet size, systems $\mu 1 R$ and $\mu 3 R$ have similar values. For system $\mu 3 R$, with reverse micelles, the value was slightly larger due to the higher amount of an oil phase, which swelled the micelles, as also observed by Silva et al. (2011). The bicontinuous structure $(\mu 2 R)$ showed a smaller droplet size because the water and oil phases were present as microphases, with surfactant molecules adsorbed at the oil/water interfaces.

\subsection{Adsorbent characterization}

The adsorbent characterization used both raw and $\mu 1 \mathrm{R}$-modified diatomite. The characterization was made only with $\mu 1 \mathrm{R}$-modified diatomite because during the experimental procedure, as detailed in the following sections, its enhanced ability for sulfur removal was proved. Distilled water (DRA) and $\mathrm{BaCl}_{2}(1500 \mathrm{mg} / \mathrm{kg})$ solution (DRB) represented the aqueous phase of the microemulsion system. The DRB was characterized for presenting the best result for adsorption capacity, and the DRA was tested to compare changes arising from aqueous phase.

An analysis of the morphological aspects of the adsorbent (Figure 4) shows the presence of many fragments of diatomaceous materials, structures with appearance of fossilized skeletons, mostly 


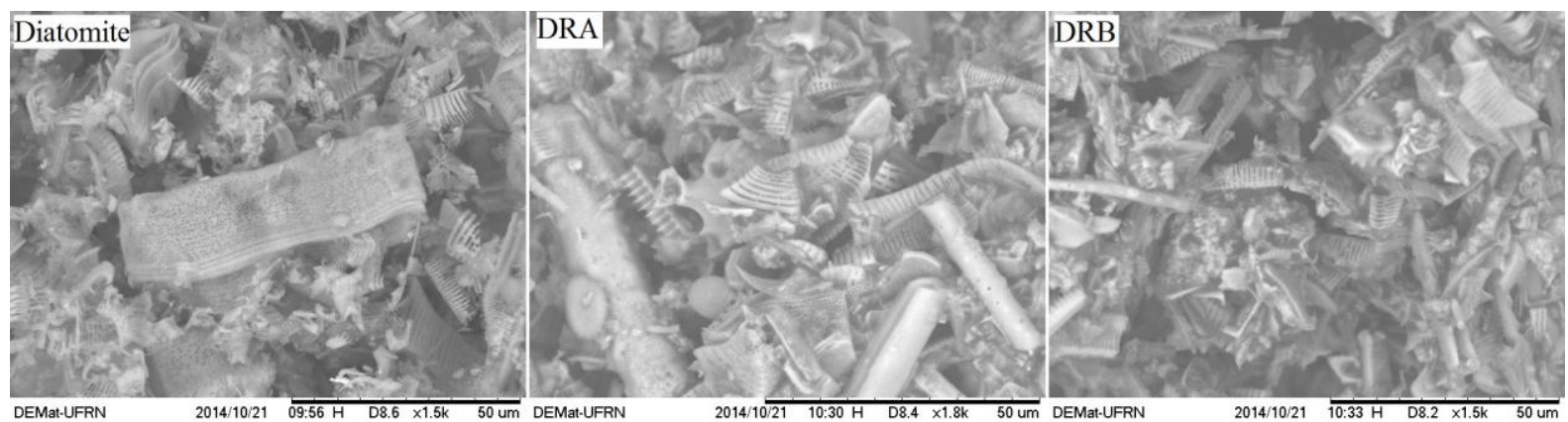

Figure 4. Micrographs from raw diatomite, DRA, and DRB adsorbents.

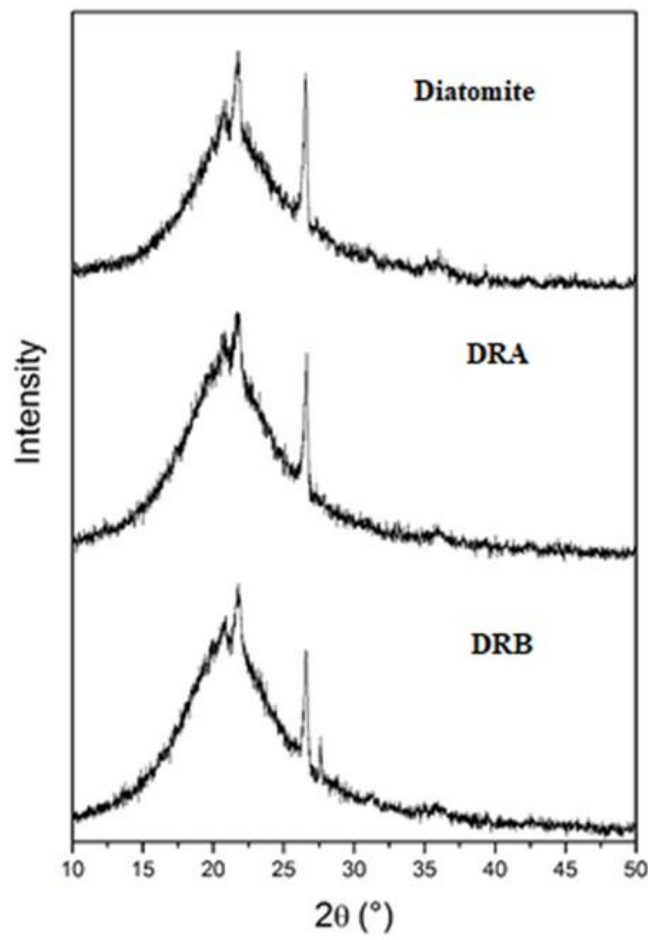

Figure 5. XRD patterns of raw diatomite, DRA, and DRB adsorbents.

tubular, with a broad size distribution. There are also many circular holes called pores (Souza et al., 2003). DRA and DRB present unchanged pores maintaining the original structures. Adsorption and filtration properties are conferred by the pores of the beehive-type arrangement.

As noted in Figure 5, XRD patterns of raw diatomite, DRA, and DRB adsorbents show three significant peaks between $20-30^{\circ}$ in the $2 \theta$ range, which are characteristic of diatomaceous materials with higher amounts of amorphous silica $\left(\mathrm{SiO}_{2}\right)$ and less of kaolinite $\left(2 \mathrm{SiO}_{2} \cdot \mathrm{Al}_{2} \mathrm{O}_{3} \cdot 2 \mathrm{H}_{2} \mathrm{O}\right)$. This result was confirmed by the XRF analysis, which found for raw diatomite, in larger quantities, 95.1\% Si, 3.1\% Al, and $1.3 \% \mathrm{Ca}$. In smaller concentrations, one could find $0.8 \% \mathrm{Fe}, 0.56 \% \mathrm{~K}, 0.22 \% \mathrm{Mg}$, and $0.1 \% \mathrm{Ti}$. One can observe that the intensity of the peak at approximately $22^{\circ}$ of $2 \theta$ increased due to microemulsion incorporation in the diatomite structure. However, the diatomite structure was preserved.

For raw diatomite, according to Figure 6 , the TG curve presents a total mass loss of about $1.75 \%$, with only one large drop at $195.7^{\circ} \mathrm{C}$. This endothermic peak can be associated to the loss of coordinated water from cations and kaolinite dehydration. For modified adsorbents, DRA and $\mathrm{DRB}$, the total mass loss was $58 \%$ at $220^{\circ} \mathrm{C}$, 

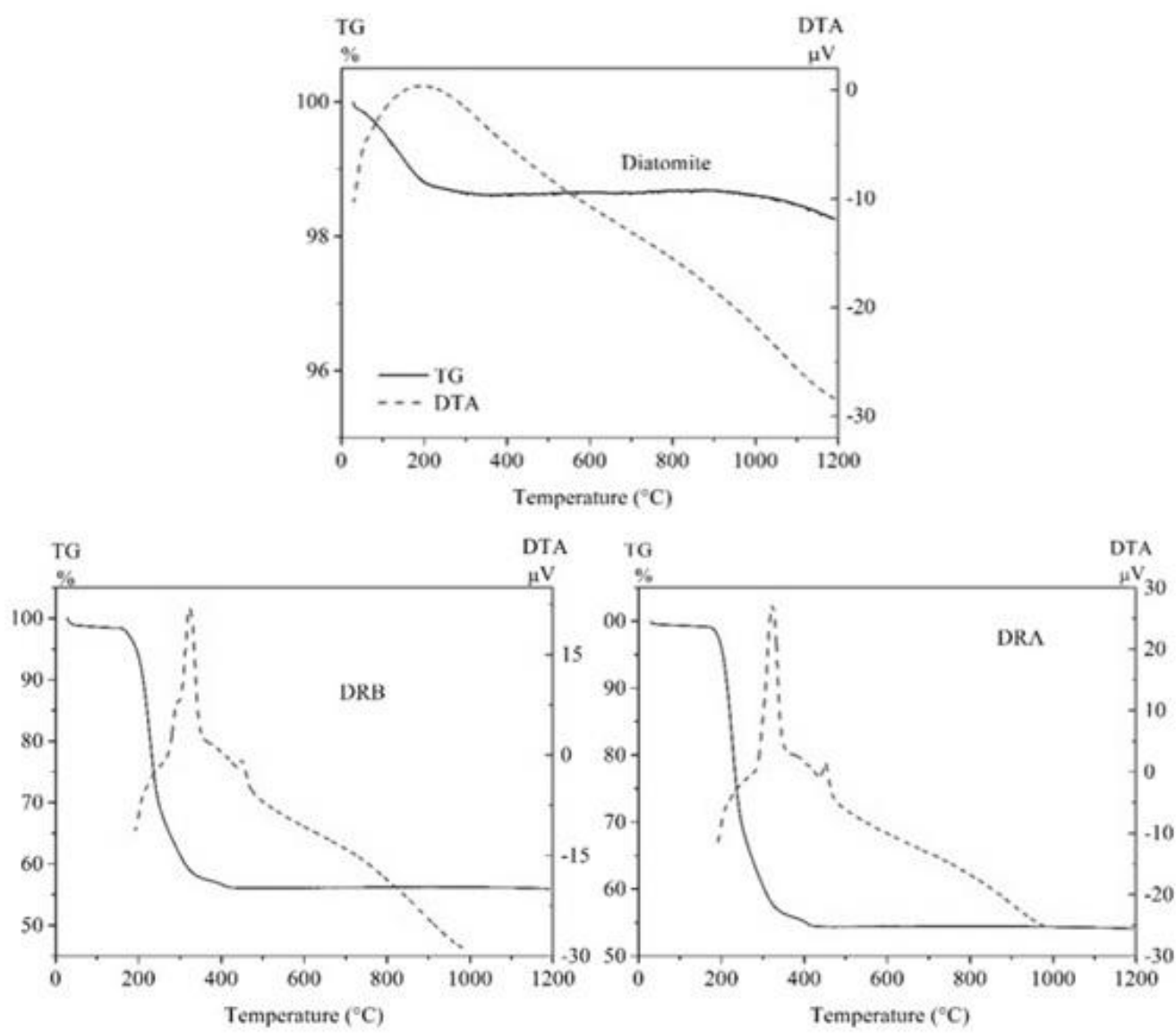

Figure 6. TG and DTA curves for raw diatomite, DRA, and DRB adsorbents.

approximately, associated with surfactant loss, since the flash point of RNX95 is $220^{\circ} \mathrm{C}$. The observed endothermic peak at $410^{\circ} \mathrm{C}$ is attributed to the dehydroxylation of the silicate lattice leading to the formation of metakaolinite. There was no significant difference in the curves with different

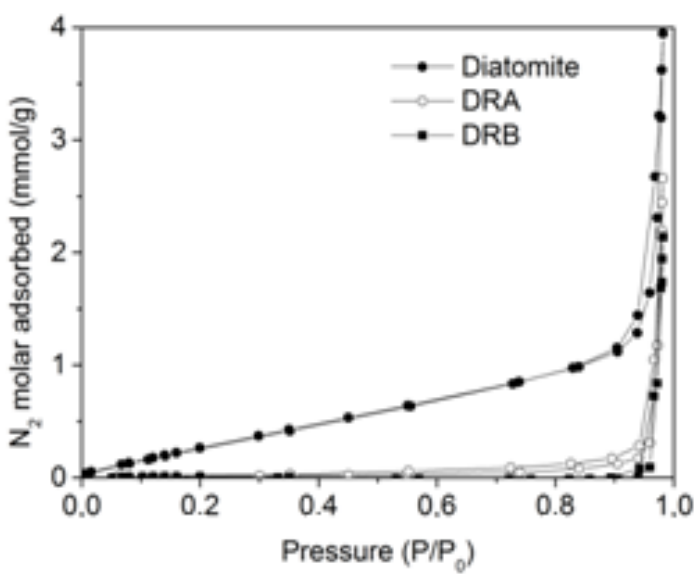

Figure 7. Adsorption-desorption $\mathrm{N}_{2}$ isotherms for raw diatomite, DRA, and DRB adsorbents. aqueous phases probably due to low salt concentration (Souza et al., 2002).

Figure 7 shows that the $\mathrm{N}_{2}$ physical adsorption isotherm is of type IV (Matthias et al., 2015). The modification of diatomite decreased the surface area because the pores were filled up with the microemulsion. Between the aqueous phases, one could observe that with the addition of salt the area decreased due to a higher occupancy caused by the presence of metal cations. The H3 type hysteresis is observed in all curves, but is considered significant only for the raw diatomite resulting in a mesopore structure of about $17 \mathrm{~nm}$ (Matthias et al., 2015).

\subsection{Sulfur adsorption experiments}

\subsubsection{Adsorption capacity of raw and modified diatomite}

To assess the effectiveness of diatomite surface modification (1:3 diatomite: modifying agent) a test was performed using raw diatomite or 
Table 5. Sulfur adsorption capacities for raw and modified diatomite $(40 \mathrm{~g}$ diatomite, $200 \mathrm{~mL}$ diesel fuel, $60^{\circ} \mathrm{C}, 18$ hours).

\begin{tabular}{cc}
\hline Type & q (mg/g) \\
\hline$\mu 1 \mathrm{R}$ & 0.36 \\
$\mu 2 \mathrm{R}$ & 0.31 \\
$\mu 3 \mathrm{R}$ & 0.19 \\
Raw diatomite & 0.01 \\
\hline
\end{tabular}

modified with the microemulsion systems. Table 5 shows the obtained results for sulfur adsorption capacity.

As observed in Table 5, the raw diatomite has no ability for sulfur removal. The $\mu 1 R$ has the highest sulfur adsorption capacity. This system has the highest percentage of active material (butan-1ol/RNX95), confirming that the surfactant is the main responsible for sulfur removal from diesel fuel. The lower sulfur adsorption capacity was obtained for $\mu 3 R$. As the continuous phase of this system is $n$-hexane and diatomite is a hydrophilic material, this may have hampered the contact of the surfactant molecules with the adsorbent surface during its modification. This can be confirmed by comparing it with $\mu 1 \mathrm{R}$, that has water as continuous phase and presented higher sulfur adsorption ability.

To evaluate the influence of salt presence in sulfur adsorption, two salts $\left(\mathrm{CaCl}_{2}\right.$ and $\left.\mathrm{BaCl}_{2}\right)$ in two different concentrations $(20 \mathrm{mg} / \mathrm{kg}$ and 1500 $\mathrm{mg} / \mathrm{kg}$ ) were used. These experiments were made by changing the aqueous phase of $\mu 1 \mathrm{R}$. The results obtained are listed in Table 6.

As shown in Table 6, the presence of salt improved the adsorption capacity as well as sulfur removal. The best results were reached when using $1500 \mathrm{mg} / \mathrm{kg}$ of salt, but low salt concentrations were sufficient to enhance adsorption ability.

Pieterse et al. (2011) achieved an adsorption capacity of $0.26 \mathrm{mg} / \mathrm{g}$ using commercial diesel with $6 \mathrm{mg} / \mathrm{kg}$ of sulfur and a nickel-based adsorbent. The experiment was conducted at $200^{\circ} \mathrm{C}$, under $500 \mathrm{rpm}$ constant stirring, for 72 hours, using $230 \mathrm{~g}$ of diesel and $6 \mathrm{~g}$ of adsorbent. Sentorun-Shalaby et al. (2011) used a commercial diesel with 14.5 $\mathrm{mg} / \mathrm{kg}$ of sulfur and a silica-alumina based adsorbent modified with nickel. The result obtained for adsorption capacity was $0.41 \mathrm{mg} / \mathrm{g}$. Sun et al. (2015) achieved $21.2 \%$ of sulfur removal as the highest value using commercial diesel and NaY zeolites. One can observe that the adsorption capacities by using this new adsorbent are in the same magnitude order of the ones obtained by these authors.

\subsubsection{Kinetic study}

Figure 8 shows sulfur adsorption capacity as a function of contact time using $\mu 1 \mathrm{R}$-modified diatomite. One can observe that the adsorption equilibrium occurs early, within only 30 minutes, reaching the maximum adsorption capacity.

For the kinetic study, the Lagergren pseudo-first order (Eq. (3)) and the Ho and McKay pseudosecond order (Eq. (4)) models were tested. In these Equations, $q_{t}$ is the adsorption capacity at time $t$ $(\mathrm{mg} / \mathrm{g}) ; \mathrm{t}$ is the time $(\mathrm{min}) ; \mathrm{q}_{\mathrm{e}}$ is the adsorption capacity at equilibrium $(\mathrm{mg} / \mathrm{g}) ; \mathrm{k}_{1}$ is the pseudofirst order equilibrium rate constant $\left(\mathrm{min}^{-1}\right)$; and $\mathrm{k}_{2}$ is the pseudo-second order equilibrium rate constant (g/mg min) (Kong et al., 2016).

Table 6. Influence of salt type and concentration in sulfur adsorption capacity and sulfur removal (40g diatomite, 200 $\mathrm{mL}$ diesel fuel, $60^{\circ} \mathrm{C}, 18$ hours).

\begin{tabular}{|c|c|c|c|}
\hline Aqueous phase & $\begin{array}{c}\text { Salt concentration } \\
(\mathrm{mg} / \mathrm{kg})\end{array}$ & $q(\mathrm{mg} / \mathrm{g})$ & Sulfur removal (\%) \\
\hline Distilled water & - & 0.36 & 11.69 \\
\hline \multirow{2}{*}{$\mathrm{CaCl}_{2}$ aqueous solution } & 20 & 1.14 & 25.23 \\
\hline & 1500 & 1.20 & 26.00 \\
\hline \multirow{2}{*}{$\mathrm{BaCl}_{2}$ aqueous solution } & 20 & 1.08 & 24.49 \\
\hline & 1500 & 1.23 & 26.53 \\
\hline
\end{tabular}




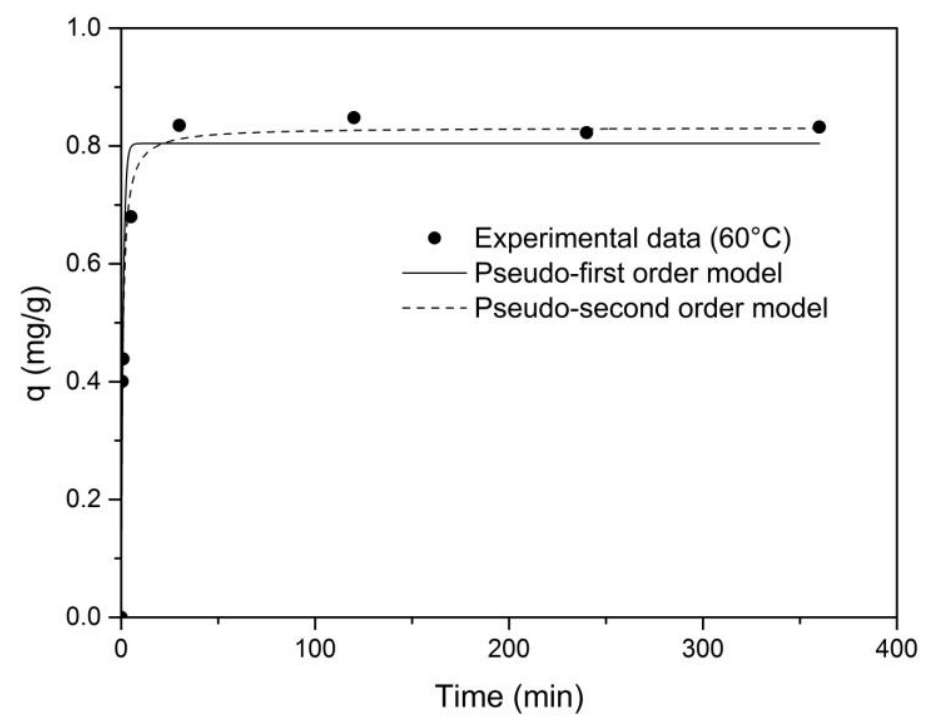

Figure 8. Sulfur adsorption capacity as a function of contact time using $\mu 1 \mathrm{R}$ modified diatomite ( $40 \mathrm{~g}$ diatomite, $200 \mathrm{~mL}$ diesel fuel, $60^{\circ} \mathrm{C}$ ).

$$
\begin{aligned}
& \mathrm{q}_{\mathrm{t}}=\mathrm{q}_{\mathrm{e} 1}\left(1-\mathrm{e}^{-\mathrm{k}_{1} \mathrm{t}}\right) \\
& \mathrm{q}_{\mathrm{t}}=\frac{\mathrm{t}}{\left(\frac{1}{\mathrm{k}_{2} \mathrm{q}_{\mathrm{e} 2}^{2}}+\frac{\mathrm{t}}{\mathrm{q}_{\mathrm{e} 2}}\right)}
\end{aligned}
$$

Table 7 shows the constants calculated using the Levenberg-Marquardt mathematical method. The highest value of correlation coefficient $\left(R^{2}\right)$ was obtained for the pseudo-second order model indicating that the adsorption data conformed well to the Ho and McKay kinetics model. This means that the adsorption rate is chemically controlled (chemisorption).

\subsubsection{Adsorption isotherms}

Langmuir (Eq. (5)) and Freundlich (Eq. (6)) isotherms models were used to study sulfur adsorption behavior on $\mu 1 \mathrm{R}$-modified diatomite.

$$
\mathrm{q}_{\mathrm{e}}=\frac{\mathrm{Q}_{\mathrm{m}} \mathrm{K}_{\mathrm{L}} \mathrm{C}_{\mathrm{e}}}{1+\mathrm{K}_{\mathrm{L}} \mathrm{C}_{\mathrm{e}}}
$$

$\mathrm{q}_{\mathrm{e}}=\mathrm{K}_{\mathrm{F}} \mathrm{C}_{\mathrm{e}}^{\frac{1}{\mathrm{n}}}$

Where $C_{e}$ is the equilibrium concentration $(\mathrm{mg} / \mathrm{L})$; $\mathrm{q}_{\mathrm{e}}$ is the adsorption capacity $(\mathrm{mg} / \mathrm{g}) ; \mathrm{K}_{\mathrm{L}}$ is the Lagmuir constant; $K_{F}$ is the Freundlich constant; $n$ is the intensity of adsorption; and $\mathrm{Q}_{\mathrm{m}}$ is the maximum adsorption capacity (mg/g) (Kong et al., 2016). The values of Langmuir and Freundlich constants are listed in Table 8. These values were obtained using the isotherms shown in Figure 9. As can be observed in Figure 9, the experimental data were better fitted to the Langmuir model $\left(R^{2}=0.99\right)$. Based on the discussion above, it is possible to

Table 7. Kinetic constants for sulfur removal using $\mu 1 \mathrm{R}$ modified diatomite.

\begin{tabular}{ccccc}
\hline \multicolumn{5}{c}{ Pseudo-first-order } \\
\hline $\mathbf{k}_{\mathbf{1}}\left(\mathrm{min}^{-1}\right)$ & $\begin{array}{c}\text { Standard } \\
\text { Error }\end{array}$ & $\mathbf{q}_{\mathrm{e} 1, \mathrm{cal}}(\mathrm{mg} / \mathrm{g})$ & $\begin{array}{c}\text { Standard } \\
\text { Error }\end{array}$ & $\mathbf{R}^{\mathbf{2}}$ \\
0.97 & 0.19 & 0.80 & 0.03 & 0.95 \\
\hline \multicolumn{5}{c}{ Pseudo-second-order } \\
$\mathbf{k}_{\mathbf{2}}(\mathrm{g} / \mathrm{mg} \mathbf{m i n})$ & $\begin{array}{c}\text { Standard } \\
\text { Error }\end{array}$ & $\mathbf{q}_{\mathrm{e} 2 \text {,cal }}(\mathrm{mg} / \mathrm{g})$ & $\begin{array}{c}\text { Standard } \\
\text { Error }\end{array}$ & $\mathbf{R}^{\mathbf{2}}$ \\
& 0.25 & 0.73 & 0.10 & 0.98 \\
\hline
\end{tabular}




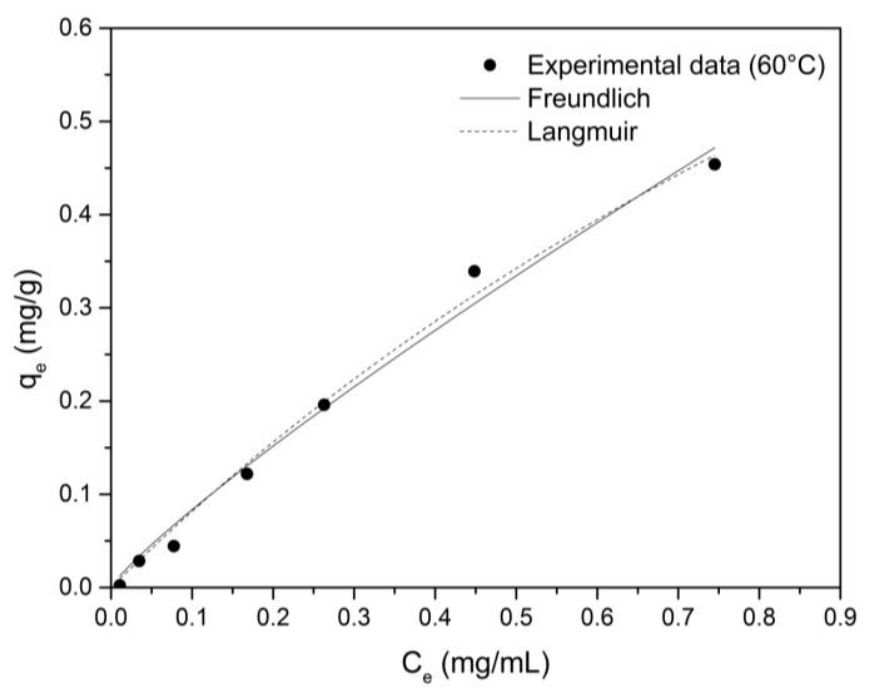

Figure 9. Langmuir and Freundlich isotherms for sulfur adsorption by $\mu 1 \mathrm{R}$ modified diatomite ( $40 \mathrm{~g}$ diatomite, 200 $\mathrm{mL}$ diesel fuel, $30 \mathrm{~min}, 60^{\circ} \mathrm{C}$ ).

conclude that adsorption occurs as monolayers, a hypothesis that was also confirmed by the studies of several authors on sulfur adsorption (Chen et al., 2016a; Jiang et al., 2010; Shalaby et al., 2009).

\subsection{Statistical analysis}

To investigate the influence of different parameters on sulfur adsorption capacity by $\mu 1 \mathrm{R}$ modified diatomite, a $2^{3}$ full factorial design was applied along with the mathematical description to optimize the process and get the highest adsorption capacity, q $(\mathrm{mg} / \mathrm{g})$. The experiments were performed using $\mathrm{BaCl}_{2}$ solution as aqueous phase. The results of the experiments are listed in Table 9.

The highest value observed for the adsorption capacity was $1.23 \mathrm{mg} / \mathrm{g}$ when sulfur, salt concentration, and temperature were at high levels. It is possible to observe that, for the lower sulfur concentrations, there is a higher number of remaining refractory compounds that are more difficult to be removed from diesel.

Effects of individual parameters and their interactions on adsorption capacity are presented in Figure 10. With the Pareto chart data, one can

Table 8. Freundlich and Langmuir adsorption parameters.

\begin{tabular}{|c|c|c|c|c|}
\hline \multicolumn{5}{|c|}{ Freundlich } \\
\hline $\mathrm{K}_{\mathrm{F}}$ & Standard Error & $n$ & Standard Error & $\mathbf{R}^{2}$ \\
\hline 0.61 & 0.03 & 1.16 & 0.09 & 0.98 \\
\hline \multicolumn{5}{|c|}{ Langmuir } \\
\hline $\mathrm{K}_{\mathrm{L}}$ & Standard Error & $\mathbf{Q}_{\mathrm{m}}$ & Standard Error & $\mathbf{R}^{2}$ \\
\hline 0.51 & 0.20 & 1.68 & 0.51 & 0.99 \\
\hline
\end{tabular}

Table 9. Average results for the experimental runs according to the $2^{3}$ full factorial design.

\begin{tabular}{cccccccccc}
\hline Run & $\mathrm{X}_{\mathbf{1}}{ }^{*}$ & $\mathrm{X}_{\mathbf{2}}{ }^{* *}$ & $\mathrm{X}_{\mathbf{3}}{ }^{* * *}$ & $\mathrm{q}_{\exp }(\mathrm{mg} / \mathrm{g})$ & $\mathrm{Run}$ & $\mathrm{X}_{\mathbf{1}}$ & $\mathrm{X}_{\mathbf{2}}$ & $\mathrm{X}_{\mathbf{3}}$ & $\mathrm{q}_{\exp }(\mathrm{mg} / \mathrm{g})$ \\
\hline 1 & -1 & -1 & -1 & 0.24 & 7 & -1 & 1 & 1 & 0.38 \\
2 & 1 & -1 & -1 & 0.23 & 8 & 1 & 1 & 1 & 1.23 \\
3 & -1 & 1 & -1 & 0.26 & 9 & 0 & 0 & 0 & 0.45 \\
4 & 1 & 1 & -1 & 0.37 & 10 & 0 & 0 & 0 & 0.41 \\
5 & -1 & -1 & 1 & 0.48 & 11 & 0 & 0 & 0 & 0.43 \\
6 & 1 & -1 & 1 & 1.08 & & & & & \\
\hline
\end{tabular}




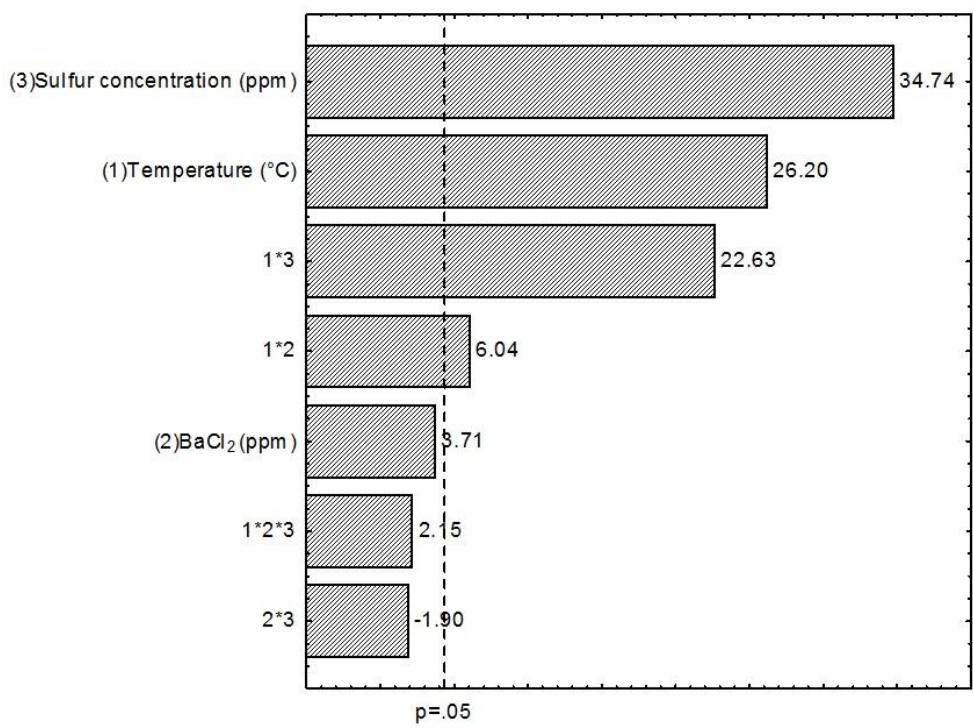

Figure 10. Pareto chart for individual parameter effects and their interactions.

conclude that salt concentration is not an important variable at the studied conditions while sulfur concentration is the most important one. Temperature is an important variable as well as the interaction between sulfur concentration and temperature, and between temperature and salt concentration.

Multiple regression analysis of experimental data, obtained by the STATISTICA 7.0 software, resulted in Eq. (7), which describes the dependence of the adsorption capacity, $\mathrm{q}(\mathrm{mg} / \mathrm{g})$. The following parameters were studied: temperature, $(T)$, sulfur concentration, $[\mathrm{S}]$, and salt concentration, $\left[\mathrm{BaCl}_{2}\right]$. By using this model, it is possible to describe how the adsorbent will behave by changing the parameter values within the range studied.

$\mathrm{q}=0.50+0.19(\mathrm{~T})+0.26[\mathrm{~S}]+$

$+0.04(\mathrm{~T})\left[\mathrm{BaCl}_{2}\right]+0.17(\mathrm{~T})[\mathrm{S}]$

The validation of the model and coefficient was carried out with the variance analysis (ANOVA), and the results are presented in Table 10. The $F$ values calculated by regression residuals were higher than the F-table values, indicating that the model is statistically significant and the coefficients are not predictive. The value for $R^{2}$ was 0.9768 . This means that the model explains $98 \%$ of the variability of the response data around its mean.

Table 10. ANOVA results - validation of model and coefficients.

\begin{tabular}{cccccc}
\hline $\begin{array}{c}\text { Source of } \\
\text { variation }\end{array}$ & $\begin{array}{c}\text { Sum of } \\
\text { Squares }\end{array}$ & $\begin{array}{c}\text { Degrees of } \\
\text { Freedom }\end{array}$ & Mean Square & $\begin{array}{c}\text { F-value } \\
\text { calculated }\end{array}$ & $\begin{array}{c}\text { F-table } \\
\text { value }\end{array}$ \\
\hline Regression & 1.09 & 7 & 0.16 & 18.09 & 8.887 \\
Residual & 0.03 & 3 & $8.6 \times 10^{-3}$ & & \\
Lack of fit & 0.02 & 1 & 0.02 & 56.39 & 18.51 \\
Pure Error & $9.0 \times 10^{-4}$ & 2 & $4.0 \times 10^{-4}$ & & \\
Total Error & 1.12 & 10 & & & \\
\hline
\end{tabular}




\section{CONCLUSIONS}

A nonionic surfactant was used in microemulsion systems for diatomite surface modification. The new adsorbents were used for sulfur removal from commercial diesel. The main conclusions of this work are:

- The raw diatomite is not capable of removing sulfur from diesel, but this removal is possible by adding a microemulsion as modifying agent;

- Finite bath adsorption studies show that the adsorption process occurs quickly, reaching its maximum value in 30 minutes;

- The salt addition positively affects sulfur adsorption capacity, without harming the pores and the diatomite structure;

- The use of a $2^{3}$ full factorial design allows one to optimize sulfur removal from commercial diesel. The best condition is achieved at $60^{\circ} \mathrm{C}, 1500$ $\mathrm{mg} / \mathrm{kg} \mathrm{BaCl}{ }_{2}$ concentration, and $1100 \mathrm{mg} / \mathrm{kg}$ sulfur concentration, reaching $1.23 \mathrm{mg} / \mathrm{g}$ of sulfur adsorption capacity and $26.53 \%$ of removal.

Finally, the use of microemulsion-modified diatomite represents a low-cost, efficient alternative to the adsorption of sulfur from commercial diesel with high sulfur contents.

\section{ACKNOWLEDGEMENTS}

This work was supported financially by the "PRH/ANP-14" Human Resources Program of the Federal University of Rio Grande do Norte and Petrobras.

\section{REFERENCES}

Aivalioti, M.; Vamvasakis, I.; Gidarakos, E. BTEX and MTBE adsorption onto raw and thermally modified diatomite. Journal of Hazardous Materials, v. 178, p. 136-143, 2010. https://doi.org/10.1016/i.jhazmat.2010.01.053

Al-Degs, Y.; Khraisheh, M.A.M.; Tutunji, M.F. Sorption of lead ions on diatomite and manganese oxides modified diatomite. Water Research, v. 35, p. 3724-3728, 2001.

https://doi.org/10.1016/S0043-1354(01)00071-9
Al-Ghouti, M.A.; Al-Degs, Y.S. New adsorbents based on microemulsion modified diatomite and activated carbon for removing organic and inorganic pollutants from waste lubricants. Chemical Engineering Journal, v. 173, p. 115-128, 2011. https://doi.org/10.1016/j.cej.2011.07.047

Al-Ghouti, M.A.; Al-Degs, Y.S.; Khalili, F.I. Minimisation of organosulphur compounds by activated carbon from commercial diesel fuel: Mechanistic study. Chemical Engineering Journal, v. 162, p. 669-676, 2010.

https://doi.org/10.1016/j.cej.2010.06.019

Al-Ghouti, M.A.; Hawari, A.; Khraisheh, M. A solid-phase extractant based on microemulsion modified date pits for toxic pollutants. Journal of Environmental Management, v. 130, p. 80-89, 2013. https://doi.org/10.1016/i.jenvman.2013.08.045

Bordoloi, N.K.; Rai, S.K.; Chaudhuri, M.K.; Mukherjee, A.K. Deep-desulfurization of dibenzothiophene and its derivatives present in diesel oil by a newly isolated bacterium Achromobacter sp. to reduce the environmental pollution from fossil fuel combustion. Fuel Processing Technology, v. 119, p. 236-244, 2014. https://doi.org/10.1016/i.fuproc.2013.10.014

Bu, J.; Loh, G.; Gwie, C.G.; Dewiyanti, S.; Tasrif, M.; Borgna, A. Desulfurization of diesel fuels by selective adsorption on activated carbons: Competitive adsorption of polycyclic aromatic sulfur heterocycles and polycyclic aromatic hydrocarbons. Chemical Engineering Journal, v. 166, p. 207-217, 2011. https://doi.org/10.1016/j.cej.2010.10.063

Chen, T.-C.; Agripa, M.L.; Lu, M.-C.; Lourdes, M.; Dalida, P. Adsorption of Sulfur Compounds from Diesel with Ion-Impregnated Activated Carbons. Energy, v. 30, p. 3870-3878, 2016.

https://doi.org/10.1021/acs.energyfuels.6b00230

Chen, Y.; Song, H.; Meng, H.; Lu, Y.; Li, C.; Lei, Z.; Chen, $\mathrm{B}$. Polyethylene glycol oligomers as green and efficient extractant for extractive catalytic oxidative desulfurization of diesel. Fuel Processing Technology, v. 158, p. 20-25, 2016. https://doi.org/10.1016/j.fuproc.2016.10.019

Chu, H.; Dong, B.; Zhang, Y.; Zhou, X.; Yu, Z. Pollutant removal mechanisms in a bio-diatomite dynamic membrane reactor for micro-polluted surface water purification. Desalination, v. 293, p. 38-45, 2012.

https://doi.org/10.1016/i.desal.2012.02.021 
Dantas, T.N.C.; Dantas Neto, A.A.; Moura, M.C.P.A.; Barros Neto, E.L.; Telemaco, E. P. Chromium Adsorption by Chitosan Impregnated with Microemulsion. Langmuir, v. 17, p. 42564260, 2001a. https://doi.org/10.1021/la001124s

Dantas, T.N.C.; Dantas Neto, A.A.; Moura, M.C.P.A. Removal of chromium from aqueous solutions by diatomite treated with microemulsion. Water Research, v. 35, p. 2219-2224, 2001b. https://doi.org/10.1016/S0043-1354(00)00507-8

Dantas, T.N.C.; Dantas Neto, A.A.; Moura, M.C.P.A.; Barros Neto, E.L.; Duarte, K.R.F. Study of new alternatives for removal of sulfur from diesel. Brazilian Journal of Petroleum and Gas, v. 8, p. 1532, 2014. https://doi.org/10.5419/bjpg2014-0002

Fallah, R.N.; Azizian, S. Removal of thiophenic compounds from liquid fuel by different modified activated carbon cloths. Fuel Processing Technology, v. 93, p. 45-52, 2012.

https://doi.org/10.1016/i.fuproc.2011.09.012

Guchhait, S.; Biswas, D.; Bhattacharya, P.; Chowdhury, R. Bio-desulfurization of model organo-sulfur compounds and hydrotreated diesel: Experiments and modeling. Chemical Engineering Journal, v. 112, p. 145-151, 2005.

https://doi.org/10.1016/i.cej.2005.05.006

Hussain, A.H.M.S.; Tatarchuk, B.J. Adsorptive desulfurization of jet and diesel fuels using $\mathrm{Ag} / \mathrm{TiO}_{x^{-}}$ $\mathrm{Al}_{2} \mathrm{O}_{3}$ and $\mathrm{Ag} / \mathrm{TiO}_{\mathrm{x}}-\mathrm{SiO}_{2}$ adsorbents. Fuel, v. 107, p. 465-473, 2013.

https://doi.org/10.1016/i.fuel.2012.11.030

Jiang, J.; Ng, F. T. T.; Jiang, J.; Ng, F. T. T. Production of low sulfur diesel fuel via adsorption: an equilibrium and kinetic study on the adsorption of dibenzothiophene onto $\mathrm{NaY}$ zeolite. Adsorption, v. 16, p. 549-558, 2010.

https://doi.org/10.1007/s10450-010-9259-5

Jiang, L.; Liu, L.; Xiao, S.; Chen, J. Preparation of a novel manganese oxide-modified diatomite and its aniline removal mechanism from solution. Chemical Engineering Journal, v. 284, p. 609-619, 2016. https://doi.org/10.1016/i.cej.2015.08.140
Julião, D.; Gomes, A. C.; Pillinger, M.; CunhaSilva, L.; Castro, B.; Gonçalves, I. S.; Balula, S. S. Desulfurization of model diesel by extraction/oxidation using a zinc-substituted polyoxometalate as catalyst under homogeneous and heterogeneous (MIL-101(Cr) encapsulated) conditions. Fuel Processing Technology, v. 131, p. 78-86, 2015.

https://doi.org/10.1016/j.fuproc.2014.10.030

Khraisheh, M.A.M.; Al-Degs, Y.S.; McMinn, W.A.M. Remediation of wastewater containing heavy metals using raw and modified diatomite. Chemical Engineering Journal, v. 99, p. 177-184, 2004. https://doi.org/10.1016/j.cej.2003.11.029

Khraisheh, M.A.M.; Al-Ghouti, M.S. Enhanced Dye Adsorption by Microemulsion-Modified Calcined Diatomite ( $\mu \mathrm{E}-\mathrm{CD})$. Adsorption, v. 11, p. 547-559, 2005. https://doi.org/10.1007/s10450-005$\underline{5612-5}$

Kong, H.; Cheu, S.-C.; Othman, N.S.; Song, S.-T.; Saman, N.; Johari, K.; Mat, H. Surfactant modification of banana trunk as low-cost adsorbents and their high benzene adsorptive removal performance from aqueous solution. RSC Advances, v. 6, p. 24738-24751, 2016. https://doi.org/10.1039/C6RA00911E

Li, E.; Zeng, X.; Fan, Y. Removal of chromium ion (III) from aqueous solution by manganese oxide and microemulsion modified diatomite. Desalination, v. 238, p. 158-165, 2009. https://doi.org/10.1016/i.desal.2007.11.062

Matthias, T.; Katsumi, K.; V, N.A.; P, O.J.; Francisco, R.-R.; Jean, R.; W, S.K.S. Physisorption of gases, with special reference to the evaluation of surface area and pore size distribution (IUPAC Technical Report). Pure and Applied Chemistry, v. 87 (9-10), p. 1051-1069, 2015.

https://doi.org/10.1515/pac-2014-1117

Muzic, M.; Sertic-Bionda, K.; Gomzi, Z.; Podolski, S.; Telen, S. Study of diesel fuel desulfurization by adsorption. Chemical Engineering Research and Design, v. 88, p. 487-495, 2010. https://doi.org/10.1016/j.cherd.2009.08.016 
Nawaf, A.T.; Gheni, S.A.; Jarullah, A.T.; Mujtaba, I.M. Improvement of fuel quality by oxidative desulfurization: Design of synthetic catalyst for the process. Fuel Processing Technology, v. 138, p. 337-343, 2015.

https://doi.org/10.1016/i.fuproc.2015.05.033

Nejad, N.F.; Shams, E.; Amini, M.K.; Bennett, J.C. Synthesis of magnetic mesoporous carbon and its application for adsorption of dibenzothiophene. Fuel Processing Technology, v. 106, p. 376-384, 2013. https://doi.org/10.1016/i.fuproc.2012.09.002

Osmanlioglu, A.E. Natural diatomite process for removal of radioactivity from liquid waste. Applied Radiation Isotopes, v. 65, p. 17-20, 2007. https://doi.org/10.1016/i.apradiso.2006.08.012

Paixão, S.M.; Arez, B.F.; Roseiro, J.C.; Alves, L. Simultaneously saccharification and fermentation approach as a tool for enhanced fossil fuels biodesulfurization. Journal of Environmental Management, v. 182, p. 397-405, 2016. https://doi.org/10.1016/i.jenvman.2016.07.099

Pieterse, J.A.Z.; van Eijk, S.; van Dijk, H.A.J.; van den Brink, R.W. On the potential of absorption and reactive adsorption for desulfurization of ultra lowsulfur commercial diesel in the liquid phase in the presence of fuel additive and bio-diesel. Fuel Processing Technology, v. 92, p. 616-623, 2011. https://doi.org/10.1016/i.fuproc.2010.11.019

Sentorun-Shalaby, C.; Saha, S.K.; Ma, X.; Song, C. Mesoporous-molecular-sieve-supported nickel sorbents for adsorptive desulfurization of commercial ultra-low-sulfur diesel fuel. Applied Catalysis B: Environmental, v. 101, p. 718-726, 2011. https://doi.org/10.1016/i.apcatb.2010.11.014

Shalaby, C.; Ma, X.; Zhou, A.; Song, C. Preparation of Organic Sulfur Adsorbent from Coal for Adsorption of Dibenzothiophene-type Compounds in Diesel Fuel. Energy \& Fuels, v. 23, p. 2620-2627, 2009. https://doi.org/10.1021/ef801135t

Silva, G.C.; Rossi, C.G.F.T.; Dantas Neto, A.A.; Dantas, T.N.C.; Fonseca, J.L.C. Characterization of wormlike micellar systems using DLS, rheometry and tensiometry. Colloids and Surfaces A: Physicochemical and Engineering Aspects, v. 377, p. 35-43, 2011.

https://doi.org/10.1016/i.colsurfa.2010.12.016
Song, H.; Wan, X.; Dai, M.; Zhang, J.; Li, F.; Song, $H$. Deep desulfurization of model gasoline by selective adsorption over $\mathrm{Cu}-\mathrm{Ce}$ bimetal ionexchanged $Y$ zeolite. Fuel Processing Technology, v. 116, p. 52-62, 2013.

https://doi.org/10.1016/i.fuproc.2013.04.017

Souza, G.P.; Filgueira, M.; Rosenthal, R.; Holanda, J.N.F. Characterization of natural diatomaceous composite material. Cerâmica, v. 49, p. 40-43, 2003. https://doi.org/10.1590/S0366$\underline{69132003000100009}$

Souza, G.P.; Sanchez, R.; Holanda, J.N.F. Characteristics and physical-mechanical properties of fired kaolinitic materials. Cerâmica, v. 48, p. 102-107, 2002. https://doi.org/10.1590/S0366$\underline{69132002000200009}$

Sprynskyy, M.; Kovalchuk, I.; Buszewski, B. The separation of uranium ions by natural and modified diatomite from aqueous solution. Journal of Hazardous Materials, v. 181, p. 700-707, 2010. https://doi.org/10.1016/i.jhazmat.2010.05.069

Subhan, F.; Liu, B.S.; Zhang, Y.; Li, X.G. High desulfurization characteristic of lanthanum loaded mesoporous MCM-41 sorbents for diesel fuel. Fuel Processing Technology, v. 97, p. 71-78, 2012. https://doi.org/10.1016/i.fuproc.2012.01.016

Sun, H.-Y.; Sun, L.-P.; Li, F.; Zhang, L. Adsorption of benzothiophene from fuels on modified $\mathrm{NaY}$ zeolites. Fuel Processing Technology, v. 134, p. 284-289, 2015.

https://doi.org/10.1016/i.fuproc.2015.02.010

Teymouri, M.; Samadi-Maybodi, A.; Vahid, A.; Miranbeigi, A. Adsorptive desulfurization of low sulfur diesel fuel using palladium containing mesoporous silica synthesized via a novel in-situ approach. Fuel Processing Technology, v. 116, p. 257-264, 2013.

https://doi.org/10.1016/j.fuproc.2013.07.009

Wang, Q.Y.; Liu, Z.L.; Zou, H.B.; Zhao, Z.H.; Wei, $X . C$. Effect of surfactant modification on the desulfurization performance of Zn/Ti-PILCs adsorbent. Journal of Fuel Chemistry Technology, v. 39, p. 203-206, 2011.

https://doi.org/10.1016/S1872-5813(11)60018-2 
Yu, W.; Deng, L.; Yuan, P.; Liu, D.; Yuan, W.; Liu, P.; He, H.; Li, Z.; Chen, F. Surface silylation of natural mesoporous/macroporous diatomite for adsorption of benzene. Journal of Colloid Interface Science, v. 448, p. 545-552, 2015.

https://doi.org/10.1016/i.jcis.2015.02.067
Yusan, S.; Gok, C.; Erenturk, S.; Aytas, S. Adsorptive removal of thorium (IV) using calcined and flux calcined diatomite from Turkey: Evaluation of equilibrium, kinetic and thermodynamic data. Applied Clay Science, v. 67-68, p. 106-116, 2012. https://doi.org/10.1016/i.clay.2012.05.012 